TILTAI, 2018, 3, 111-125 ISSN 1392-3137 (Print), ISSN 2351-6569 (Online)

\title{
VISUOMENĖS SVEIKATA IR ETIKA: PRAKTIKOS IR MOKSLINIŲ TYRIMŲ RAIDOS DISKURSAS
}

\author{
Birutė Jatkauskienė, Sigutė Norkienė \\ Klaipédos universitetas
}

\begin{abstract}
Anotacija
Straipsnyje pristatomas visuomenės sveikatos etikos praktikos, kaip socialinio veiksmo, ir mokslinių tyrimų raidos diskursas. Siekiant tikslo suformuluoti keli probleminiai klausimai: kur glūdi visuomenès sveikatos koncepto daugiaprasmiškumo priežastys; kaip suprantamas visuomenès konceptas visuomenès sveikatos sampratos kontekste; kokios galimos visuomenès sveikatos etikos analizès prieigos; kuo iš esmès skiriasi visuomenès sveikatos ir sveikatos priežiūros etika? Pirmoje straipsnio dalyje analizuojama visuomenès sveikatos koncepto daugiaprasmiškumo raiška. Antra straipsnio dalis skirta visuomenès sampratai visuomenès sveikatos koncepto kontekste. Trečioje dalyje atskleidžiamos visuomenès sveikatos etikos analitinès prieigos (profesinè, taikomoji, atstovavimo, kritinè etika). Ketvirtoje dalyje akcentuojami visuomenès sveikatos ir sveikatos priežiūros etikos skirtumai. Apibendrintas visuomenès sveikatos etikos raidos istorinis diskursas atskleidžia straipsnio tikslo teorinių prieigų dinamiškumą.
\end{abstract}

PAGRINDINIAI ŽODŽIAI: etika, visuomenès sveikata, sveikatos etikos analitinės prieigos.

\begin{abstract}
The purpose of the article is to present a discourse of public health ethics, as a social action, and research development. The following problematic questions have been framed to achieve the above purpose: what are the reasons for multiple meanings of public health concept? How is the concept of public in the context of pubic health understood? What are the possible approaches to the analysis of public health ethics? What are the major differences between public health ethics and healthcare ethics? The first part of the article makes an analysis of multiple meanings of the concept of public health. The second part addresses the concept of public in the context of public health. In the third part, there are analytical approaches to public health ethics reflected (professional ethics, applied ethics, representation ethics, critical ethics). The fourth part of the article focuses on differences between public health ethics and healthcare ethics. A summarising historical discourse on the development of public health ethics reveals the dynamics of theoretical approaches to the purpose of the article.
\end{abstract}

KEY WORDS: ethics, public health, analytical approaches to health ethics.

DOI: http://dx.doi.org/10.15181/tbb.v79i3.1895

\section{Ivadas}

Visuomenės sveikatos ir net bioetikos atstovams buvo, kartais vis dar yra gana sudètinga pagrịsti savają specifinę etiką. Manyta, kad deontologinè prieiga, grindžiama teisėmis arba medicinos, sveikatos priežiūros etikos principais (autonomija, gerovè, nekenkimas ir teisingumas) sudaro visuomenès sveikatos etikos pagrindą. Tačiau, įvertinus globalius visuomenės sveikatos orientavimo strateginius tikslus, akivaizdu, kad nei medicinos, nei sveikatos priežiūros etika negali suteikti 
tinkamo visuomenès sveikatos praktikos pagrindo, kaip ir tinkamo normatyvinio visuomenès sveikatos praktikos paaiškinimo (MacDonald, 2013). Medicinos etika dažniausia nukreipta ị individus klinikiniame kontekste, tuo tarpu visuomenès sveikatos etika nukreipta ị gyventojus, kaip bendruomenę (Zahner, 2000). Remiantis šiais teiginiais, galima teigti, kad visuomenès sveikatos etika yra gana nauja taikomosios etikos šaka.

Visuomenès sveikatos praktikams seniai kyla tam tikrų etinių iššūkių, tačiau iki šiol vis dar trūksta pagrịstų teorijų, nuostatų, kurios padètų analizuoti etiką, remiantis pagrindinėmis visuomenès sveikatos vertybèmis ir principais.

Jau prieš penkis dešimtmečius akcentuotos visuomenès sveikatos etikos reikmès, tačiau tik XX amžiaus pabaigoje ir XXI amžiaus pradžioje visuomenès sveikatos etikoje įsitvirtino kaip paskira studijų ir analizès sritis (Kass, 2004). Todėl manytina, kad ị visuomenès sveikatos etikos raidą svarbu žvelgti iš istorinès, filosofinès perspektyvos. Straipsnio tikslas - pristatyti visuomenès sveikatos etikos praktikos, kaip socialinio veiksmo, bei mokslinių tyrimų raidos diskursą.

Formuluojami šie probleminiai klausimai:

- Kokios yra visuomenès sveikatos koncepto daugiaprasmiškumo priežastys?

- Kaip suprantamas visuomenés konceptas visuomenès sveikatos sampratos kontekste?

- Kokios yra galimos visuomenès sveikatos etikos analizès prieigos?

- Kokie yra pagrindiniai visuomenès sveikatos ir sveikatos priežiūros etikos skirtumai?

\section{Visuomenès sveikatos koncepto daugiaprasmiškumo problema}

Viena galimų šio koncepto daugiaprasmiškumo priežasčiu - visuomenès sveikatos konceptas šnekamojoje kalboje buvo, kartais vis dar netinkamai interpretuojamas, siejamas su sveikatos priežiūros sistemoje teikiamomis paslaugomis, kurios finansuojamos valstybinių fondų (Verweij, Dawson, 2007, p. 17). M. Verweij'aus, A. Dawson'o nuomone, daugiaprasmị visuomenès sveikatos koncepto interpretavimą lèmè tai, kad dažnai visuomenès sveikatos specialistai veikia lyg ir užkulisiuose, tuo tarpu plačioji visuomenè to nesuvokia, kol neivvyksta krizè, kai tenka imtis radikalių priemonių ir veiksmų, susijusių su visuomenès sveikata. Tuo tarpu sveikatos priežiūros sistema žmonių gyvenime reiškiasi dažniau ir konkrečiau, todèl ji labiau suprantama.

Žvelgiant iš istorinès perspektyvos, mokslinèse publikacijose, kur apibrèžiamas visuomenès sveikatos konceptas, kartojasi pagrindiniai teiginiai, pabrèžiantys kolektyvines pastangas, atsakomybę visuomenei ir dèmesį sveikatos socialiniams 
bei aplinkos determinantams: „Visuomenės sveikata - tai ligu prevencijos, gyvenimo trukmès pailginimo, sveikatos stiprinimo menas ir mokslas, pasitelkus struktūruotas visos visuomenès pastangas“ (Acheson, 1988, p. 1); „Visuomenės sveikata reiškia tai, ką mes bendrai veikiame kaip visuomenè, stengdamiesi užtikrinti, kad mūsų gyvenimo sąlygos būtų sveikos“(Institute of Medicine, 1988, p. 1); „Visuomenès sveikata - tai visuomenès pastangos saugoti, stiprinti ir sugrąžinti gyventojų populiacijos sveikatą. Tai vienu metu mokslo, kompetencijų, tikẻjimo sveikatos palaikymu bei stiprinimu visuma, igyvendinama kolektyviniais ir bendruomeniniais veiksmais" (Last, 2004, p. 205).

Akivaizdu, kad beveik kiekvienoje pateiktoje visuomenès sveikatos apibrèžtyje galima įžvelgti ir moralinị tikslą - kilstelèti visuomenès sveikatos lygị, kaip socialinị gèrị, užtikrinantị kitų socialinių tikslų siekị. Populiacijos sveikatos vertinimas, sveikatos stebèsena, ligu ir traumu, savižudybiu prevencija, sveikatos apsaugadažniausia koncepto apibrèžtyse minimos visuomenès sveikatos pagrindinès funkcijos.

Pastaraisiais dešimtmečiais, išaugus marginalių ar rizikos grupėms priklausančių visuomenės individų skaičiui, visuomenès sveikatos funkcijos papildomos paslaugu prieinamumo visiems visuomenès nariams funkcija (Kenny, Sherwin, Baylis, 2010).

Kadangi visuomenès sveikata orientuota ị visos visuomenès narių sveikatos stiprinimą, taikomos veiklos strategijos nukreiptos ne tik ị individus. Veikla, savo prigimtimi skirta visuomenei, vykdoma vietos, regiono, valstybinių visuomenès sveikatos institucijų. Vis dèlto dar ir šiandien valstybès dèmesys visuomenès sveikatos priežiūrai, atsižvelgiant ị asmens sveikatos priežiūrą, nepakankamas. Ši sritis, priešingai nei asmens sveikata, visuomenei nẻra gerai žinoma. Kai visuomenèje diskutuojama dèl sveikatos apsaugos, jos reformų, dažniausia turima omenyje asmens sveikatos priežiūra - pacientai ir jų teisès, gydymo ịstaigos, jų pajègumai ir galimybès. Tuo tarpu apie visuomenès sveikatos priežiūrą asmuo retai gali ką nors pasakyti, jei su šia sritimi nebuvo susidūręs.

Išskirtinis visuomenės sveikatos bruožas - visos visuomenės, jos struktūrų ir individų atsakomybė už savo bei kitų sveikatą, aktyvus dalyvavimas, sprendžiant sveikatos problemas, kurių vien medicina negali išspręsti.

Gyventojų aprūpinimas geriamuoju vandeniu, saugių maisto produktų tiekimas, higienos reikalavimai ir jų laikymasis, užkrečiamų ligų prevencija - tai tik keletas visuomenès sveikatos veiklos pavyzdžių, kur reikia ne tiek individualių, kiek kolektyvinių pastangų. Tokią kolektyvinę veiklą dažnai būtina teisiškai reglamentuoti, ji gali apeliuoti ị individų moralinę teisę, todèl visa tai suponuoja aiškios ir konkrečios visuomenès sveikatos etikos reikmes. 


\section{Visuomenės samprata visuomenės sveikatos koncepto kontekste}

Kalbėdami apie visuomenès sveikatą kai kurie autoriai (Childress, Faden, Gaare, Gostin, Kahn, Bonnie, Kass, Mastroianni, Moreno, Nieberg, 2002) pažymi, kad visuomenè šiame kontekste gali būti suprantama keliomis prasmėmis:

- skaitmeniné visuomené, kuri suprantama kaip tikslinè populiacijos grupé, visuma individų, kuriais remiantis pagrindžiami visos gyventojų populiacijos sveikatos duomenys;

- politine visuomene, atskleidžianti tai, kas yra kolektyviai padaryta, nuveikta igyvendinus visuomeninių institucijų ir vyriausybės tarpininkavimą; politinè visuomenè reiškia įstatymo suteiktą vyriausybès atsakomybę dèl sveikatos apsaugos;

- bendruomenine visuomene reiškiasi kitoje bendruomenės ir socialinėje veikloje, kurios tikslas - sveikatos stiprinimas už profesionalų, jų institucijų teikiamų paslaugų ir praktikos ribų, tai gali būti ịvairios nevyriausybinès organizacijos, piliečiai, privačios asmenu grupès ir kt.

Žinoma ir dar vaizdingesnè visuomenès koncepto samprata, kai visuomenè apibrěžiama kaip ,,individų bendrija, susieta sudètingais instituciniais ir kultūriniais mechanizmais, kurių dèka ir kuriuose jie veikia bei gyvena“ (Jennings, 2007, p. 36).

B. Jennings'o (2007) teigimu, visuomenès konceptas yra normatyvinis, paaiškina, kaip turi būti struktūruota sistema ir kaip turètų atrodyti bei būti organizuotas mūsų visų bendrabūvis. Taigi visuomenè - tai daugiau nei individų grupè, tai yra kompleksinè sistema, sudaryta iš tarpusavyje sąveikaujančių bei vienas nuo kito priklausančių elementų. Tai visuma, pasižyminti savybėmis, kurios neatsiskleidžia individualiose sudedamosiose dalyse. Todèl idejja, pagal kurią populiaciją sudaro pavieniai nepriklausomi elementai, atmetama. B. Jennings'o teigimu, etiškos elgsenos suvokimas turi būti išreikštas „,sąvokomis ir konceptais, kurie atskleistų asmens, žmogaus, socialinę bei kontekstualizuotą bendravimo, reikšmingų santykių prigimtį“ (Jennings, 2007, p. 37). Tokia visuomenès koncepto samprata, akcentuojanti žmonių tarpusavio santykių reikšmę, numato atsirandančias visuomenès sveikatos etikos analizès prieigas. Kitaip tariant, tarpusavio santykių ir socialinis visuomenès reikšmingumas visuomenès koncepto sampratos kontekste tampa ¡̇kvėpimo šaltiniu visai visuomenès sveikatos etikai. Be to, šis visuomenės koncepto bruožas ịgalina geriausiai suprasti, kuo skiriasi visuomenès sveikatos etika nuo sveikatos priežiūros etikos. 


\section{Visuomenės sveikatos etikos analizès prieigos}

Visuomenès sveikatos etika gali būti analizuojama, taikant kelias analitines perspektyvas:

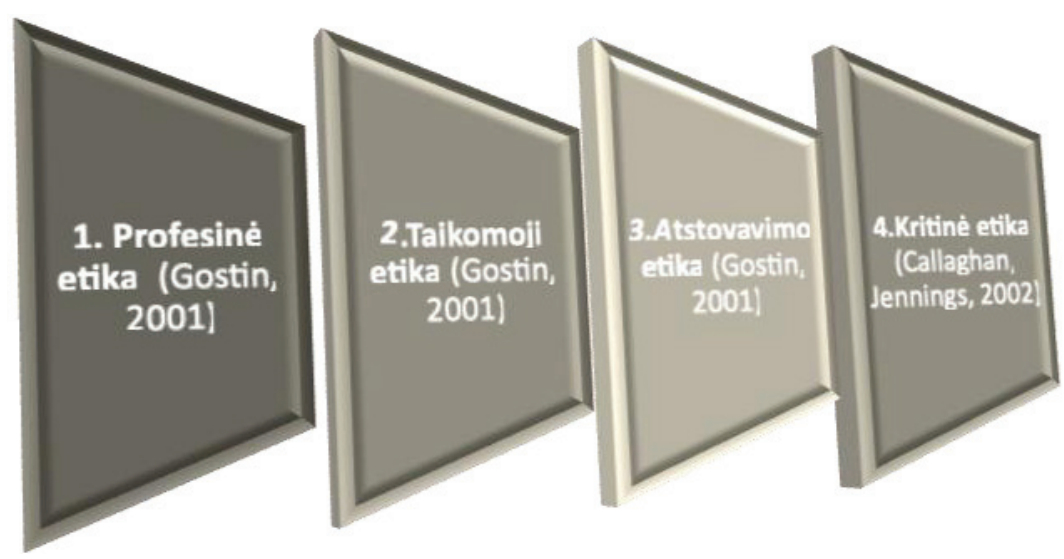

1 pav. Visuomenès sveikatos etikos analizès prieigos (remiantis Gostin 2001; Callaghan, Jennings, 2002)

Profesine etika susieta su visuomenès sveikatos misija - saugoti arba stiprinti sveikatą. Ši etika nukreipta ị visuomenès sveikatos praktikos vertybes, profesinị visuomenès sveikatos pobūdị. Mokslinėse visuomenès sveikatos etikos publikacijose, teisès dokumentuose galima pastebèti didelę vertybių ịvairovę, jos tampa visuomenès sveikatos veiklos orientavimo, organizavimo ar vertinimo gairemis. Tačiau kyla klausimas, kurios šių vertybių geriausiai tinka visuomenès sveikatos praktikos veiksmų etikos analizei? Ar visomis vertybėmis galima remtis, analizuojant ịvairius visuomenès sveikatos praktikos veiksmus? Ir kaip suprantamos vertybės visuomenès sveikatos kontekste? Išsamiau domintis moksline literatūra visuomenès sveikatos vertybių raiškos problematikos klausimais, jas siejant su visuomenès sveikatos etikos ir kitais klausimais, galima teigti, kad vertybių sąrašas skirtingas, tačiau galima stebèti trijų tipų vertybių grupes, kurias galima pasitelkti visuomenės sveikatos etikos analizei: visuomenei reikšmingos visuomenės sveikatos veiksmų vertybès, vertybės, susietos su visuomenès sveikatos tikslais, ir profesinès vertybès.

Visuomenès sveikatos praktikai yra atsakingi už etines normas ir etikos kodeksą. Dar šio tūkstantmečio pradžioje JAV parengtas etikos kodeksas, skirtas visuomenès sveikatos praktikams (Public Health Leadership Society, 2002). Deja, ne visos šalys gali tuo pasigirti. 
Profesinè visuomenès sveikatos etika teikia atsakymus ị tokius gana sudètingus klausimus: kam visuomenès sveikatos specialistai turi būti lojalūs? Klientams? Pacientams? Visai bendruomenei? Ar visoms išvardytoms grupėms? Kaip visuomenès sveikatos praktikai gali žinoti, kokie veiksmai yra morališkai priimtini? Kaip etikos principu besilaikantis visuomenès sveikatos praktikas galètų pasitarnauti bendruomenei?

Taikomoji etika išreiškia principus, kurie taikytini konkrečioje visuomenès sveikatos praktiko etikos situacijoje (Gostin, 2001). Ji yra specifinè ta prasme, kad padeda konkrečiu atveju apibrèžti morališkai priimtinus sprendimus. Tačiau reikètų akcentuoti ir tai, kad principai, padedantys priimti sprendimus konkrečioje visuomenès sveikatos situacijoje, tampa etikos diskusijų objektu, nes jų yra gana daug, be to, nerandama konsensuso dẻl jų svarbos eiliškumo. Paprastai tenkinamasi susitarimu, kad medicinos etikos principai (autonomija, gerovè, nekenkimas ir teisingumas) ne visada gali būti taikomi visuomenès sveikatai dèl jų individualistinès prigimties ir to, kad nukreipti ị klientų (pacientų) teises, o ne ị bendrą gerovę (Kass, 2001). Todėl bandyta apibrezžti etikos principus, kurie labiausiai atitinka moralinius visuomenès sveikatos tikslus: solidarumas, bendravimo savarankiškumas, socialinis teisingumas, savitarpiškumas (Baylis ir kt., 2008; Upshur, 2002 ir kt.).

Atstovavimo etika (angl. advocacy ethics) pasižymi ne tik teorine analize, bet ir praktika, kuri yra dažnesnè. Visuomenès sveikatos praktikai dažnai save suvokia kaip atstovaujančius vienam ar kitam reikalui. Atstovavimo etika grindžiama tam tikros pozicijos veiklos tikslų, intervencijos ar reformų atžvilgiu užèmimu, siekiant ịgyvendinti visuomenès sveikatos moralinius principus. Ji reiškiasi gana stipria orientacija ị socialinị teisingumą. Teigiama, kad atstovavimo, arba visuomenès sveikatos, etika kartais turi tam tikrą populizmo atspalvị (Gostin, 2001), nes ji dažnai gina marginalių asmenų interesus. Viena iš atstovavimo problemų - visuomenès sveikatos praktikus gali riboti užimama pozicija visuomenès sveikatos institucijos padalinyje ar ministerijoje, esant akivaizdžiam dvilypiam jų lojalumui. B. Jennings'as (2007) atkreipè dèmesį i tai, kad atstovavimo etika tik ribotai gali išreikšti kritinę profesinių normų ar orientacijos perspektyvą galingų suinteresuotų grupių atžvilgiu.

Kritine etika išryškina visuomenès sveikatos klausimus, kurie kartais gali būti sunkiai ịžvelgiami dẻl kai kurių tradicinių mąstymo ar veiklos būdų (Nixon, 2006). Kritinè etika remiasi istorine perspektyva, orientuota ị visuomenès sveikatos praktiką, įvertina socialines tendencijas ir vertybes, analizuojant tiek aktualią dabarties visuomenès sveikatos situaciją, tiek moralinius tokią situaciją sukèlusius veiksnius, nes pastarieji reiškiasi kaip ,instituciniai mechanizmai, socialinès galios struktūros ir kultūrinès nuostatos" (Callaghan, Jennings, 2002, p. 172) bei vienaip ar kitaip veikia visuomenès sveikatos sritị. Remiantis kritinės etikos analizės perspektyva, politika ir įvairios intervencijos turètų atskleisti tikras visuomenès pa- 
stangas, nes kritinè etika pabrèžia pilietinio dalyvavimo, atviros diskusijos, problemų sprendimo reikšmingumą ir pilietinių gebẻjimų ugdymą. Pilietinio dalyvavimo ịsipareigojimas turi senas visuomenès sveikatos tradicijas, grindžiamas ịvairiomis filosofinėmis koncepcijomis bei demokratija. Kritinès pastangos mums leidžia dar kartą pažvelgti ị tai, ką ịgijome, pamąstyti, kaip reprezentuojami valdžios santykiai visuomenės sveikatos srityje. Remiantis kritine etika, galima ieškoti ir surasti atsakymą ị klausimą, kodèl ir kieno interesams tai atstovauja? Nes visuomenès sveikata - tai pirmiausia socialinio teisingumo reikalas. Galima teigti, kad šiandien iš tiesų padaugèjo mokslinių straipsnių kritinės etikos tematika, taigi kritinei etikai tenka prioritetinė vieta visuomenès sveikatos mokslinių tyrimų lauke.

\section{Visuomenès sveikatos ir sveikatos priežiūros etikos skirtumų raiška}

Visuomenès sveikatos ir sveikatos priežiūros etikos skirtumai grindžiami visuomenès sveikatos ir sveikatos priežiūros atskyrimu. Sveikatos priežiūra ir jos etika (medicinos etika) nukreipta ị individualius pacientų, gaunančių sveikatos priežiūros paslaugas klinikiniame kontekste bei sąveikaujančių su visa sveikatos priežiūros sistema, poreikius, interesus, problemas, jiems siekiant pasveikti. Visuomenės sveikata ir jos etika - priešingai, orientuota ị visos populiacijos, sudarytos iš įvairių asmenų grupių, gyvenimo aplinką. Visuomenès sveikata ir jos etika ypač domisi, kaip šias grupes veikia politinès ir socialinès struktūros, aplinkos veiksniai. Net jei visuomenès sveikata ir jos etika orientuota ị visos populiacijos interesus, didelis dèmesys skiriamas rizikos grupių, marginalių, engiamų, išnaudojamų asmenų teisingumo, bešališkumo, prieinamumo klausimams, kurie susiję su sveikatos sritimi.

Teigiama, kad pagrindinès visuomenès sveikatos charakteristikos kelia specifinius moralinius iššūkius (Dawson, Verweij, 2007):

- Visuomenès sveikatos sektoriuje iniciatyva kyla iš visuomenès sveikatos profesionalų, o ne iš kliento, paciento pusès. Tradicinès visuomenès sveikatos strategijos: atvejų paieška, partnerių notifikacija (svarbaus fakto pranešimas) ir kt., implikuoja profesionalo ejimą pas pacientą, klientą, kai tenka pasitelkti ịtikinèjimą ar pateikti svarių argumentų, užtikrinti pagrindinę priežiūrą, siekiant apsaugoti visą populiaciją. Klinikinė aplinka yra palanki pacientams savanoriškai atvykti konsultuotis su profesionalais.

- Su visuomenès sveikata susijusios intervencijos skirtos visai gyventojų populiacijai, todèl individuali asmens nauda gali būti ignoruojama. Taip reiškiasi vadinamasis klasikinis „prevencijos paradoksas“. Kai kurios intervencijos, teigiamai veikiančios visą populiaciją, pavienių asmenų gali nesudominti, kartais tokios iniciatyvos jiems gali netgi pakenkti. 
- Su visuomenès sveikata susijusios intervencijos gali būti visa apimančios, todèl individams gali būti sudètinga atsisakyti jose dalyvauti. Vandens prisodrinimas fluoru, saugos diržų naudojimosi reglamentavimas, vairavimas apsvaigus, privaloma vakcinacija ir kt. yra gana ryškūs šio specifinio moralinio iššūkio pavyzdžiai.

Sveikatos priežiūros, klinikinèje aplinkoje pirmiausia tenkinami individualūs asmens, o ne visos populiacijos sveikatos interesai. Kai kurių autorių (Nixon ir kt., 2005) nuomone, visuomenès sveikatos srityje pasigendama aiškių ir reglamentuotų sutarčių tarp visuomenès sveikatos praktiko ir jo paslaugas gaunančio asmens, kaip ịprasta sveikatos priežiūros srityje. Todèl visuomenès sveikatos veiklos orientacija į visą gyventojų populiaciją implikuoja sutartį su visa visuomene, kuriai atstovauja įteisinta vyriausybinè visuomenès sveikatos politika.

Teigiama, kad „vertybès ir fundamentali visuomenès sveikatos praktika, kuri dažnai reikalauja individo paklusimo dèl bendros gerovès, galimai oponuoja bioetikos ideologinėms srovèms" (Bayer, Fairchild, 2004, p. 474). Kartu akcentuojama, kad visuomenès sveikatos etikoje taikytinos normos negali atsirasti iš bioetikos hipotezių, tokių kaip dominuojantis individualizmas ar autonomijos principo akcentavimas.

N. Daniels'o (2006) teigimu, iš pradžių bioetika buvo orientuota ị: pacientų ir gydytojų arba kitų veikejjų, teikiančių sveikatos priežiūros paslaugas, santykius (sveikatos priežiūros etika); tyrèjus ir į jų tyrimo subjektus (mokslinių tyrimų etika); klausimus ir problemas, susijusias su naujų technologijų taikymu.

Anot N. Daniels'o (2006), problema ta, kad bioetika ignoravo globalesnius institucinius ir politinius mechanizmus, kurie turẻjo ịtakos gyventojų populiacijos sveikatai. Kitaip tariant, bioetika nebuvo linkusi atsižvelgti ị kontekstą, kuriame vystosi ir konkrečiai reiškiasi paciento ir gydytojo ar kito veikejjo, teikiančio sveikatos priežiūros paslaugas, tyrèjo ir jo subjekto tarpusavio santykiai. Naujosios technologijos atitolino bioetiką nuo bendriausių sveikatos determinantų, sudarančių visuomenès sveikatos pagrindą. Taip bioetika nutolo nuo socialinio teisingumo idejjų, nebėra nešališka. Ir kiti autoriai (Baylis ir kt., 2008) tvirtino, kad bioetika labai retai kreipia dèmesị ị socialinius sveikatos determinantus.

Visuomenès sveikatos etika turi prasidèti visuomenès sveikatos fundamentaliụjų vertybių, principų (solidarumo, bendravimo savarankiškumo, socialinio teisingumo, savitarpiškumo) pripažinimu, o ne sveikatos priežiūros sistemai aktualių vertybių, kito pobūdžio sąveikų principų modifikavimu. 


\section{Visuomenès sveikatos etikos raidos istorinės ịžvalgos}

Nors daugelio šalių visuomenès sveikatos etikos specialistai pažymi išaugusias solidžios, patikimos ir reikšmingos visuomenès sveikatos etikos reikmes, ne visos šalys (išskyrus JAV ir Jungtinę Karalystę, kai kurias kitas) gali pasigirti dedančios čia pastangas ir turinčios konkrečių rezultatų. Praejjusio dešimtmečio visuomenès sveikatos etikos teoriniai darbai (Baylis ir kt., 2008; Kenny ir kt., 2010) įnešè didžiulị indèlį, praplečiant visuomenès sveikatos etikos prasmę, išryškinančią tai, kad mes visi esame socialios ir viena nuo kitos priklausomos būtybès.

Istorijos perspektyvoje galima ịžvelgti kelis visuomenès sveikatos etikos raidos etapus.

I etapas. Apie 1970-1980 metus atsiradęs ir išpopuliarejęs sveikatos stiprinimo konceptas bei kilusi AIDS grèsmė lèmė visuomenès sveikatos etikos bazės kūrimąsi. Tačiau tik antrajame etape pradètas grịsti visuomenès sveikatos etikos teorinis pagrindas, siekiant atskirti visuomenès sveikatos etikos sriti nuo medicinos etikos srities bei pakeisti utilitaristines teorijas, ịvertinus visus filosofinius, politinius svarstymus, siūlymus. Trečiasis etapas skirtas ateities perspektyvoms, jų projekcijai, tarptautiniam teisingumui, aplinkosaugai ir visuomenės sveikatos srities mokslinių tyrimų etikai. Pirmasis etapas prasidejjo su sveikatos stiprinimo idejos atsiradimu, kuris tapo visuomenès sveikatos dèmesio centru. Iki to laiko visuomenès sveikatos etika neegzistavo, o jos filosofinis pagrindas nebuvo išanalizuotas ir išdiskutuotas. Todèl sveikatos stiprinimo idẻja buvo grindžiama liberaliaja filosofija ir bioetika, kurios sureikšmino autonomijos principą (Kass, 2004). Itteisintos valstybès ar profesionalų intervencijos, kurių tikslas - savanoriška individų elgsenos kaita (pavyzdžiui, dietos, pratybos, alkoholio, tabako atsisakymas ir kt.) kèlé daug klausimų, nes edukacinio ir ịtikinejjimo pobūdžio intervencija galëjo kelti grèsmę asmens laisvei ir autonomijai. Manyta, kad tokia intervencija, kai pasitelkiamas įtikinėjimas, tam tikras psichologinis spaudimas, žmonès verčiami atsisakyti savo ankstesnès elgsenos, ịpročių, troškimų, net jei tai nekelia grèsmès aplinkiniams, yra neetiška. Taigi po labai gausios etikos specialistų kritikos sveikatos stiprinimo idejja, akcentuojanti savanoriškus elgsenos pokyčius, patyrẻ pokyčių. Sveikatos stiprinimo idèjoje atsirado kitų akcentų: pabrěžiami socialiniai ir bendruomeniniai pokyčiai, akcentuojami sveikatos socialiniai ir politiniai determinantai, teigiamai veikiantys sveikatą. Toks naujas žiūros taškas kèlẻ kitokio pobūdžio susirūpinimą - paternalizmas, egzistuojantis teigiamai visuomenès sveikatą veikiančioje politikoje. Medicinos etikoje paternalizmas buvo suvokiamas vos ne kaip keiksmažodis (Jones, Bayer, 2007), todèl visuomenès sveikatos atstovai turejo atstovèti savo pozicijas, teigdami, kad daugelis visuo- 
menès sveikatos politikos elementų yra paternalistinio pobūdžio. Dètos pastangos suteikti paternalizmo sąvokai kitą prasmę, ją siejant su bendravimo, tarpusavio santykių etika, bendruomenine refleksija (Gostin, Gostin, 2009; Jennings, 2009 ir kt.).

Pasaulyje išplitus AIDS grèsmei, suintensyvejjo diskusijos etikos klausimais, kurių objektas - politinio atsako į šią grèsmę paieškos. Analizuojant moralinius ligos klausimus, medicinos etikos specialistai iš pradžių, kaip ir sveikatos stiprinimo idejos atveju, susitelkè ties pačiais principais ir vertybėmis (Bayer, Fairchil, 2004). Pasirodžius AIDS, visuomenès sveikatos sistema jau turèjo visą eilę parengtų procedūrų, taikytinų užkrečiamų ligų atvejais ir skirtų joms aptikti, skirti priežiūrą, deklaruoti ir notifikuoti, siekiant kad liga neplistų ir netaptų epidemija. Tuo metu aiškiai suvokta, kad AIDS labai skiriasi nuo kitų užkrečiamų ligų, todèl šios ligos atvejis, palyginus su kitomis užkrečiamomis ligomis, apibūdintas kaip AIDS išskirtinumas (Smitt, Whiteside, 2010). Tai reiškè, kad naudotos ne tik įprastos visuomenès sveikatos sistemoje taikomos praktikos ir prevencijos priemonės, bet teko rinktis ir kitus prevencijos metodus, kurie atitiktų žmogaus individualias teises, siekiant apsaugoti visuomenès sveikatą. Visa tai, savaime suprantama, lèmé atitinkamus visuomenès sveikatos etikos normų pokyčius.

II etapas. Apie 2000-uosius visuomenès sveikatos etikai pasiūlytos pagrindinès metodologinès nuostatos, normos ir principai, turintys filosofinị pagrindimą bei išdiskutuoti etikos specialistų ir mokslininkų publikacijose. Šiame etape atsiranda ir pirmieji moksliniai žurnalai, skirti visuomenès sveikatos etikai. Lygiagrečiai su visuomenès sveikatos etika, formuojasi ir feministinė bei slaugos etika, kurios remiasi tais pačiais principais: autonomija bendraujant (tarpusavio santykiuose), solidarumas, socialinis teisingumas. Tie patys principai pradèti taikyti, sprendžiant specifines visuomenès problemas: moterų, vaikų patiriamas smurtas, prievarta ir kt. Verta paminèti ir tai, kad šie visuomenès sveikatos etikos principai taikyti medicinos etikos kontekste, neịvertinus fakto, kad minètų visuomenės sveikatos problemų analizè iš etikos perspektyvos galëjo palengvinti bendresnio pobūdžio visuotinès visuomenès sveikatos etikos rengimą (Pauly, 2008). Antrajame visuomenės sveikatos etikos raidos etape pastebimos vis didėjančios kitų šaliu (ne tik JAV ir Jungtinès Karalystės) pastangos populiarinti visuomenės sveikatos etiką, grindžiant jos teorinius, filosofinius, politinius pamatus.

III etapas. Šiame etape brèžiamos visuomenès sveikatos etikos ateities perspektyvos. Išryškejja trys pagrindinès kryptys (MacDonald, 2013; Kass, 2004): teisingumas aplinkosaugos sektoriuje, visuomenès sveikatos etikos moksliniai tyrimai, tarptautinis teisingumas.

Teisingumas aplinkosangos sektoriuje - tai teisingas rizikos, naudos, pasekmių, atsakomybės aplinkosaugos srityje pasidalijimas tarp paskirų šalių, nes visuome- 
nės sveikatai aktualus nešališkumas ne tik sveikatos srityje, bet ir visos mus supančios sveikos aplinkos mastu. Mus gali stebinti faktas, kad visuomenès sveikatos etika šiai sričiai skyrè nepakankamai dėmesio, todèl šiame etape išryškèja nauja visuomenès sveikatos etikos perspektyva.

Visuomenés sveikatos etikos moksliniai tyrimai ateityje turètų detaliau apibrèžti visuomenès sveikatos tyrimų specifiką, nustatant ir ịvertinant, ar tokie moksliniai tyrimai gali išgryninti specifinius probleminius etikos klausimus, kas leistų išskirti atskirą mokslo šaką (visuomenès sveikatos mokslinių tyrimų etika).

Tarptautinis teisingumas reiškia, kad visuomenès sveikatos etika turi būti orientuota ị tarptautinị teisingumą, kur nešališkumo ir sveikatos tarpusavio ryšiai būtų dar glaudesni nei iki šiol ir reikštųsi ne tik regioniniu, valstybiniu, bet ir tarptautiniu mastu.

Atpažinti ir padaryti tinkamu veiksmą, susijusị su visuomenès sveikata, lygiomis visų individų galimybėmis, autonomija, bendruomeniškumu - didžiausi visuomenès sveikatos etikos iššūkiai, nes etika, tai pirmiausia refleksijos apie tikslus ir priemones analizè, samprotavimo ir veiksmo paaiškinimo priemonè, žodynas ir veikla, leidžiantys struktūruoti prieštaringas idèjas ir diskutuoti sudètingų sprendimų prièmimo atvejais.

Visuomenès sveikatos etika semiasi naujų idẻjų, šaltinių iš kitų mokslų disciplinų. Tai palengvina skirtingų visuomenès sveikatos etikos tikslų siekimą, o visuomenès sveikatos etikai rodomas tyrẻjų dèmesys leidžia daryti prielaidą, kad pastaroji žada tapti perspektyvia mokslo disciplina.

\section{Išvados}

1. Remiantis atlikta mokslinès literatūros analize, galima teigti, kad daugiaprasmis visuomenés sveikatos koncepto interpretavimas atsirado todèl, kad visuomenès sveikatos veikla pavieniams visuomenès nariams ne taip akivaizdžiai matoma, kaip sveikatos priežiūros veikla.

2. Visuomenės koncepto samprata, akcentuojanti žmonių tarpusavio santykių reikšmę, numato atsirandančias visuomenès sveikatos etikos analizès prieigas. Ši visuomenès koncepto savybė igalina geriausiai suprasti visuomenès sveikatos ir medicinos ar sveikatos priežiūros etikos skirtumą.

3. Rèmimasis ịvairiomis filosofinèmis, naujomis teorinėmis ịžvalgomis, ịvairialype visuomenès sveikatos srities praktika užtikrina visuomenès sveikatos etikos spartesni vystymąsi. Visuomenès sveikatos etika pamažu ,jaukinasi“ ịvairias visuomenès sveikatos praktikas, išryškinant ịvairius šios praktikos etikos aspektus ir analitines prieigas (profesinę, taikomają, atstovavimo, kritinę etiką). 
4. Atlikus mokslinès literatūros analizę, galima teigti, kad egzistuoja gana didelis sveikatos priežiūros etikos ir vertybių, sudarančių visuomenès sveikatos etikos pagrindą, skirtumas. Visuomenès sveikatos etika turi prasidèti visuomenès sveikatos fundamentaliųų vertybių, principų (solidarumo, bendravimo savarankiškumo, socialinio teisingumo, savitarpiškumo) pripažinimu, o ne sveikatos priežiūros sistemai aktualių vertybių, kito pobūdžio sąveikų principų modifikavimu.

\section{Literatūra}

Acheson, D. (1988). Public health in England. London: HMSO.

Baylis, F., Kenny, N. P., Sherwin, S. (2008). A relational account of public health ethics. Public Health Ethics, Vol. 1 (3), p. 196-209.

Bayer, R., Fairchild, A. L. (2004). The genesis of public health ethics. Bioethics, Vol. 18 (6), p. $473-492$.

Callaghan, D., Jennings, B. (2002). Ethics and public health: Forging a strong relationship. American Journal of Public Health, Vol. 92 (2), p. 169-176.

Childress, J. E., Faden, R. R., Gaare, R. D., Gostin, L. O., Kahn, J., Bonnie, R. J., Kass, N. E., Mastroianni, A. C., Moreno, J. D., Nieberg, P. (2002). Public health ethics: Mapping the terrain. Journal of Law, Medicine \& Ethics, Vol. 30, p. 170-178.

Daniels, N. (2006). Equity and population health: Toward a broader bioethics agenda. Hastings Centre Report, Vol. 36 (4), p. 22-35.

Dawson, A., Verweij, M. (2007). Introduction: Ethics, prevention and public health. In A. Dawson, M. Verweij (eds.). Ethics, prevention, and public health, p. 1-12. New York: Oxford University Press.

Gostin, L. O., Gostin, K. G. (2009). A broader liberty: J. S. Mill, paternalism and the public's health. Public Health, Vol. 123, p. 214-221.

Gostin, L. O. (2001). Public health, ethics and human rights: A tribute to the late Jonathan Mann. Journal of Law, Medicine \& Ethics, Vol. 29, p. 121-130.

Institute of Medicine. (1988). The future of public health. Washington, DC: National Academies Press.

Jennings, B. (2009). Public health and liberty: Beyond the Millian paradigm. Public Health Ethics, Vol. 2 (2), p. $123-134$.

Jennings, B. (2007). Public health and civic republicanism: Toward an alternative framework for public health ethics. In A. Dawson, M. Verweij (eds.). Ethics, prevention and public health, p. 30-58. New York: Oxford University Press.

Jones, M. M., Bayer, R. (2007). Paternalism and its discontents: Motorcycle helmet laws, libertarian values, and public health. American Journal of Public Health, Vol. 97 (2), p. 208-217.

Kass, N. (2004). Public health ethics: From foundations and frameworks to justice and global public health. Journal of Law, Medicine \& Ethics, Vol. 32, p. 232-242.

Kass, N. E. (2001). An ethics framework for public health. American Journal of Public Health, Vol. 91 (11), p. $1776-1782$.

Kenny, N. P., Sherwin, S., Baylis, F. (2010). Revisioning public health ethics. Canadian Journal of Public Health, Vol. 101 (1), p. 9-11.

Last, J. M. (2004). Dictionnaire d'épidémiologie, enrichi d'un lexique anglais-français. Saint-Hyacinthe: Edisem inc.

MacDonald, M. (2013). Ethics of public health. In J. L. Storch, P. Rodney, R. Starzomski (eds.). Toward a moral horizon: Nursing ethics for leadership and practice. Pearson Education Canada.

Nixon, S. (2006). Critical public health ethics and Canada's role in global public health. Canadian Journal of Public Health, Vol. 97 (1), p. 32-34.

Nixon, S., Upshur, R. E. G., Robertson, A., Benatar, S. R., Thompon, A. K., Daar, A. S. (2005). Public health ethics. In D. T. M. Bailey, T. Caulfield, N. M. Ries (eds.). Public health law \& policy in Canada, p. 39-58. Markham, ON: LexisNexis Butterworths. 
Pauly, B. (2008). Harm reduction through a social justice lens. International Journal of Drug Policy, Vol. 19, p. 4-10.

Public Health Leadership Society. (2002). Principles of the ethical practice of public health.

Smith, J. H., Whiteside, A. (2010). The history of AIDS exceptionalism. Journal of the International AIDS Society, Vol. 13 (47), p. 1-8. Prieiga internete: https://onlinelibrary.wiley.com/doi/full/10.1186/1758-265213-47\#reference]

Upshur, R. E. G. (2002). Principles for the justification of public health intervention. Canadian Journal of Public Health, Vol. 93 (2), p. 101-103.

Verweij, M., Dawson, A. (2007). The meaning of "public" in "public health." In A. Dawson, M. Verweij (eds.). Ethics, prevention, and public health, p. 13-29. New York: Oxford University Press.

Zahner, S. J. (2000). Ethics content in community health nursing textbooks. Nurse Educator, Vol. 25 (4), p. 186194.

\section{PUBLIC HEALTH AND ETHICS: A DISCOURSE OF PRACTICE AND RESEARCH DEVELOPMENT}

\section{Birutė Jatkauskienė, Sigutė Norkienè}

Summary

The purpose of the article is to present a discourse of public health ethics, as a social action, and research development. The following problematic questions have been framed in the article: what are the reasons for multiple meanings of public health concept? How is the concept of public in the context of pubic health understood? What are the possible approaches to the analysis of public health ethics? What are the major differences between public health ethics and healthcare ethics?

The first part of the article attempts to clarify the reasons for multiple meanings of the concept of public health. Analysis of scientific literature presumes that multiple interpretations of the concept of public health are due to the fact that public health activities often seem to take place behind the scenes, as individuals hardly ever interfere with them directly. Meanwhile, the health care system is more frequent and more explicit in people's lives, thus, better perceived and understood. The state devotes insufficient attention to public healthcare, with regard to personal healthcare. Public awareness of this area is not high, unlike personal health. Where public debate of healthcare and its reforms takes place, it usually involves personal health care, i.e., patients and their rights, healthcare facilities, their capacities and feasibilities. However, if an individual has not come across public healthcare before, he or she can little say about this area. Thus, an ordinary citizen does not even realise that public health is the science and art of preventing disease, prolonging life and promoting health and efficiency through organized community effort for the sanitation of the environment, the control of communicable infections, the education of the individual in personal hygiene, the organization 
of medical and nursing services for the early diagnosis and preventive treatment of disease, and for the development of the social machinery to insure everyone a standard of living adequate for the maintenance of health, so organizing these benefits as to enable every citizen to realize his birthright of health and longevity. A distinctive feature of public health is the responsibility of society as a whole, its structures and individuals for their own and other people's health as well as their active involvement in finding responses to health problems that cannot simply be solved by medical assistance.

The second part addresses the concept of public in the context of public health. It should be noted that public in the context of public health might be interpreted in several ways: as numerical, political and community-based public. The latter is aimed to strengthen health beyond professional or institutional services and practices. It emphasises interpersonal relations, joint efforts of the community in strengthening public health. The concept of public, that focuses on significance of interpersonal relations, affords emerging approaches to the analysis of public health ethics. In other words, social significance of interpersonal relations and public in terms of public becomes a source of inspiration for public health ethics. This aspect of the concept of public enables the best understanding of the difference between public health ethics and medical, or, healthcare ethics.

Public health ethics may be analysed through a number of analytical approaches. This is reflected in the third part. Professional ethics (or public health ethics) focuses on values of public health practices. Academic works and legal documents on public health ethics show a large variety of values, which have a potential of becoming guidelines for orienting, organising, or assessing public health activities. The questions, however, arise: which values in general are best suited for the analysis of ethics in public health practices? Would all values be invoked in analyzing various elements of public health practices? And (...) how are the values in the context of public health understood? A deeper analysis of scientific literature and the topic of the expression of values in public health, in conjunction with public health ethics and others aspects, allows stating that the list of values varies. Yet, there can be groups of three types of values distinguished to be used for the analysis of public health ethics: values of public health practices of public significance, values related to public health goals, and professional values. Applied ethics (or ethics in public health) represents the principles applicable to a specific ethical situation of a public health practitioner. Representation ethics (or ethics for public health) is based on taking a certain position in terms of operational objectives, intervention, or reforms so as to attain ethos of public health. It manifests itself as a rather strong commitment to social justice. Critical ethics emphasises the significance of civic participation, open discussion, problem-solving, and civic capacity building. 
The fourth part of the article focuses on differences between public health ethics and healthcare ethics, which are explained by separation of public health and health care. Healthcare and ethics thereof (medical ethics) are focused on individual needs, interests, and problems of patients who receive healthcare services in a clinical context and interact with the entire healthcare system so as to recover.

In the final part, historical insights into the development in public health ethics are presented. From the perspective of history, there are three main phases in the development of ethics in public health.

Drawing on multiple philosophical and new theoretical insights, on a wide variety of public health practices allows for faster development of public health ethics. The ethics of public health is gradually becoming a "home" for diverse public health practices and highlights various aspects of ethics in this area (professional, applied, representation, critical ethics).

The analysis of scientific literature suggests that there is a relatively large gap between healthcare ethics and the values that underpin ethics in public health. Healthcare ethics is a description and analysis of different elements of healthcare through the open expression and provision for ethical norms, a disclosure of human and societal images that underpin and display such norms, and critical examination of human nature of this fundamental approach. The public health ethics should start with the recognition of fundamental values and principles of public health (solidarity, communicative independence, social justice, reciprocity), rather than with a modification of values that are used in healthcare, yet, intended for other types of interactions.

Identification of an action relating to public health, equal opportunities, autonomy, sociality and making it right are the greatest challenges in public health ethics. Nevertheless, ethics is, first of all, an analysis of reflection on objectives and means, a tool for reasoning and action justification, vocabulary, and activity that enables to structure conflicting ideas and to hold a discussion in complex decision-making situations. 
